\title{
PENDAMPINGAN SISTEM PEMBELAJARAN ONLINE BERBASIS APLIKASI GOOGLE MEET BAGI GURU-GURU SMP IT DAARUL ISTIQLAL DAN SMP IT RAHMAT MARINDAL I, KECAMATAN PATUMBAK, KABUPATEN DELI SERDANG
}

\author{
Rafika Dewi Nasution ${ }^{*}$, Farida Hanim Saragih', Puan Suri Mira A. Sembiring ${ }^{3}$ \\ ${ }^{1}$ Program Pendidikan Bahasa Inggris, Jurusan Bahasa dan Sastra Inggris, Fakultas Bahasa dan Seni, \\ Universitas Negeri Medan, Medan, Indonesia \\ e-mail: faridahanimsaragih@ unimed.ac.id
}

\begin{abstract}
Abstrak
Peningkatkan kualitas pembelajaran pada siswa SMP IT Daarul Istiqlal dan SMP IT Rahmat melalui kegiatan pendampingan terhadap guru-guru dalam pengembangan sistem pembelajaran online berbasis aplikasi Google Meet bagi guru-guru. Kegiatan penelitian ini dilakukan dengan melakukan proses pendampingan sistem pembelajaran online berbasis aplikasi yang disebarluaskan kemasyarakat khususnya di sekolah-sekolah sebagai pemecah persoalan pengembangan pembelajaran di era pandemi covid-19.Berdasarkan hasil kegiatan didapat simpulan bahwa pembelajaran online dapat meningkatkan proses belajar mahasiswa yang lebih mandiri, kreatif serta inovatif. Apabila materi yang disampaikan pada google meeting dirancang secara detail, dan sistematis, maka pembelajaran bahasa inggris di SMP IT Daarul Istiqlal dan SMP ITRahmat Marindal I Kecamatan Patumbakdapat meningkatkan kualitas pengetahuan siswa. Kendala yang dihadapi dalam proses pembelajaran online ini dapat dilakukaan dengan kegiatan sosialisasi lebih intens diantara guru, guru dengan siswa. Selain itu, mencari solusi alternatif dalam menghadapi kendala diantaranya siswa mencari alternatif dengan memakai modem internet pribadi, warnet, atau dengan menggunakan aplikasi wifi.id berbayar yang telah disediakan oleh pihak sekolah guna meminimalisir kendala. Secara umum, pembelajaran berbasis online ini manarik, menantang kemandirian siswa dalam belajar dan sebagai solusi terbaik di massa pandemic covid-19 yang menuntut physical distancing.
\end{abstract}

Kata kunci: Bahasa Inggris; Google Meet; Pandemi Covid-19; Pembelajaran Online

\begin{abstract}
The development of quality of education for junior high school students at SMP IT Daarul Istiqlal and SMP IT Rahmat Patumbak through mentoring activity for teachers to advance the online learning system using google meet. The study was conducted by giving mentoring about the online learning application system to school as the solution to the education problem in Covid-19. Based on the result of the study, it could be seen that the online learning system can maximize the process of learning and made students more independent, creative, and innovative. The material given through google meet designed in detail and systematic, give a positive impact on the student's learning outcome of English subject in SMP IT Daarul Istiqlal and SMP IT Rahmat Marindal I Patumbak. The problem faced by the teachers in the online teaching and learning process could be improved by the good communication and socialization between teacher to teacher and teacher to student virtually. Moreover, to overcome the other problem, the student can find another way to keep connected by using a personal hotspot, through internet cafes, or using prepaid wifi.id given by the school. In general, due to physical distancing rules, the online learning system is interesting and challenging for the student to prepare them to be more independent in learning process in the Covid-19 pandemic.
\end{abstract}

Keywords: Covid-19 Pandemic; Google Meet; English; Online Learning System 


\section{PENDAHULUAN}

SMP IT Daarul Istiqlal dan SMP IT Rahmat adalah Sekolah Menengah Pertama (SMP) yang berlokasi di Propinsi Sumatera Utara Kec. Marindal I Kab. Deli Serdang. Jumlah keseluruhan kelas yang di kelola MTS Daarul Istiqlal adalah 15 Kelas, jumlah 500 murid dan jumlah guru 40 yang tidak jauh berbeda dengan SMP IT Rahmat . Kegiatan pembelajaran didukung oleh seluruh guru mata pelajaran, fasilitas laboratorium komputer dan kimia, perpustakaan, kantin serta mushalla. Berikut ini deskripsi visual sekolah SMP IT Daarul Istiqlal dan SMP IT Rahmat.
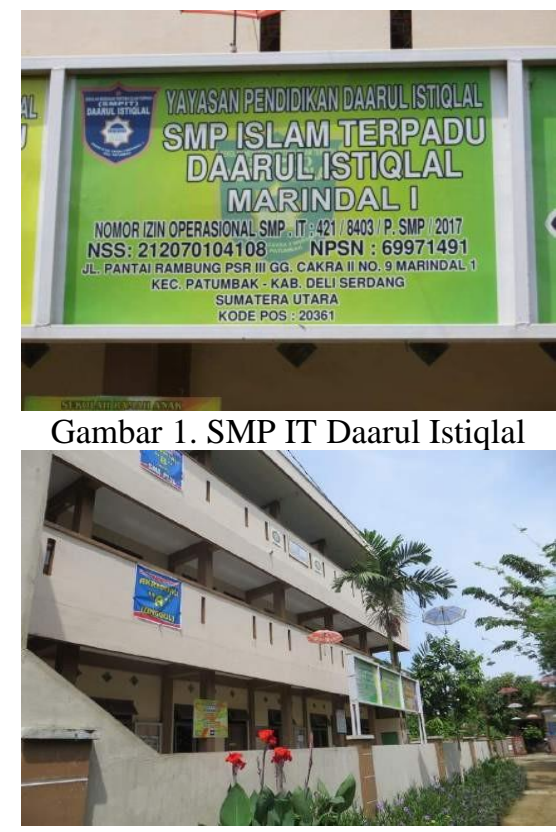

Gambar 2. SMP IT Daarul Istiqlal

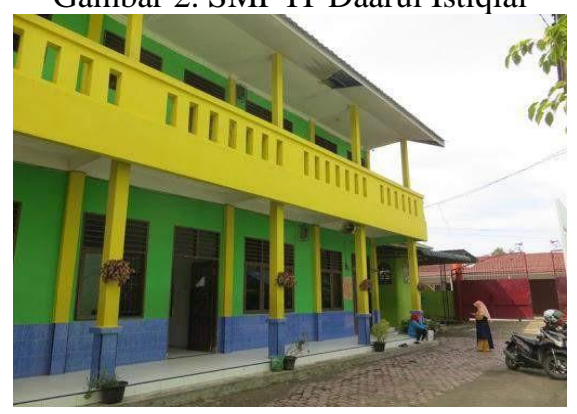

Gambar 3. SMP IT Rahmat

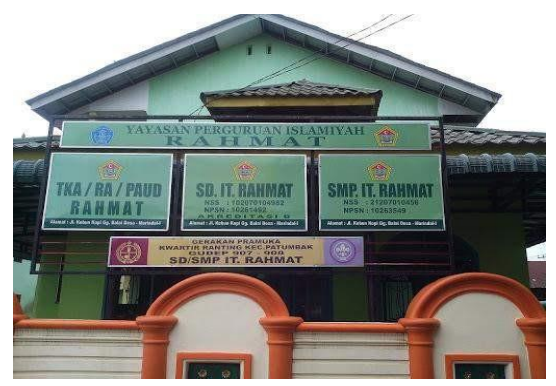

Gambar 4. SMP ITRahmat
Kondisi ini mencerminkan bahwa sekolah tersebut telah didukung oleh Sumber Daya Manusia (SDM) yang memadai dan cukup berkualitas. Meskipun demikian kualitas sekolah tersebut masih belum begitu baik.

Namun, 3 bulan belakangan ini proses kegiatan belajar mengajar di SMP IT Daarul Istiqlal dan SMP IT Rahmat mengalami kendala yang diakibatkan oleh Pandemi Covid-19. Berdasarkan surat edaran Mendikbud No 4 Tahun 2020 Tentang Pelaksanaan Kebijakan Pendidikan dalam Masa Darurat Penyebaran Corona Virus Disease (Covid-19) dimana dinyatakan bahwa proses belajar dari rumah melalui pembelajaran daring/jarak jauh. Aktivitas dan tugas pemblajaran Belajar dari Rumah dilakukan bervariasi antar siswa,sesuai kondisi masing-masing, dan mempertimbangkan kesenjangan akses/fasilitas dari rumah. Berdasarkan informasi terkini Presiden Joko Widodo (Jokowi) telah menargetkan kurva virus corona baru penyebab Covid-19 akan turun pada Mei 2020 ini. Sementara peneliti Singapura memprediksi wabah itu berakhir di Indonesia di Oktober 2020. Ditengah kekhawatiran penyebaran virus corona COVID-19, Rektor Universitas Negeri Medan (Unimed) Syamsul Gultom juga mengeluarkan surat edaran terkait penerapan bekerja dari rumah atau Work From Home (WFH). Rektor Universitas Telkom Adiwijaya menyatakan pandemi virus korona (covid19) mengakibatkan perubahan secara tiba-tiba dalam bidang pendidikan, sehingga belajar dari rumah merupakan keniscayaan. Sekitar 7,5 juta mahasiswa dan hampir 45 juta pelajar sekolah dasar dan menengah pun 'dipaksa' untuk melakukan pembelajaran dari rumah. Oleh sebab itu, banyak hal kendala yang dihadapi SMP IT Daarul Istiqlal dan SMP IT Rahmat dalam pelaksanaan pembelajaran daring/jarakJauh.

Berikut beberapa permasalahan khusus dan mendasar yang menjadi prioritasuntuk diintervensi agar kualitas pembelajaran jarak jauh guru dan siswa dapat diperbaiki, dan akan berdampak pada peningkatan pengetahuan siswa, diantaranya , 1) fasilitas Jaringan Internet, 2) tingkat pengetahuan Siswa, 3) minimnya kemampuan guru dalam pelaksanaan pembelajaran jarakjauh, 4) kumpulan Bahan Ajar sesuai dengan capaian pembelajaran.

Berdasarkan pada hasil analisis atas kondisi tersebut diatas maka peroleh data yaitu (1) kreativitas guru dalam mengembangkan media dan bahan ajar masih harus tingkatkan guna meminimalisir kendala yang tidak dapat dikendalikan dikemudian hari, (2) pemanfaatan Iptek dalam penyelenggaraan kegiatan pendidikan yang di buat oleh guru masih kurang, dan (3) rendahnya kualitas guru dalam mengembangkan bahan ajar berbasis online. Berdasarkan pada 
masalah-masalah tersebut, Tim pengabdian pada masyarakat dan sekolah tersebut berpendapat bahwa masalah prioritas yang perlu diselesaikan yaitu peningkatan kualitas guru dalam mengembangkan pembelajaran jarak jauh dan penyusunan bahan ajar sesuai dengan kebutuhan guna tercapaiannya tujuan pembelajaran. Dengan begitu, pengembangan rencana pembelajaran pada akhirnya akan berpengaruh pada peningkatan mutu lulusan SMP IT Daarul Istiqlal dan SMP IT Rahmat.

Pemanfaatan teknologi untuk proses belajar mengajar dapat memberikan kontribusi yang baik untuk meningkatan kualitas pembelajaran, akan tetapi disisi lain pemanfaatan teknologi bisa menimbulkan hal yang negatif apabila salah digunakan. Hal tersebut disampaikan oleh Dr. Purwanto, M.Pd dari Pusat Teknologi Informasi dan Komunikasi Pendidikan Kemendikbud

(https://ulm.ac.id/id/2017/10/20/pemanfaatan-

teknologi-untuk-pendidikan/).

Institusi pendidikan di Indonesia mulai berlombalomba mememanfaatkan Teknologi Informasi dan Komunikasi (TIK) untuk pendidikan denganmembangun infrastruktur hardware, jaringan internet, pengadaan sofware dan lain sebagainya, yang semua itu dilakukan dalam usaha memenuhi kebutuhan akan metode pembelajaran yang lebih efektif dan efisien. Pelatihan-pelatihan dengan pemanfaatan aplikasi komputer pun sering diselenggarakan seperti; Intelligent Tutoring System (ITS), Computer Basad Training (CBT), dan eLearning System (Hariningsih,2005).

Iptek dapat berjalan dengan baik dalam pembelajaran jika dilengkapi dengan bahan ajar yang sesuai dengan kebutuhan pembelajaran siswa. Bahan ajar disusun sesuai dengan jenis mata pelajaran dan tujuan pembelajaran. Menurut (Pannen dalam Sadjati, 2012). Bahan ajar adalah bahan atau materi pelajaran yang disusun secara sistematis, yang digunakan guru dan siswa dalam proses pembelajaran Pertanyaannya sekarang, apakah bahan ajar sudah sesuai dengan dikategorikan atau kriteria bahan ajar yang dibutuhkan. Melalui kegiatan pendampingan ini semua kesulitan akan ditupas tuntas. Bagaimana guru dibimbing dalam penyusunan bahan ajar serta pelaksanaan pembelajaan dengan memanfaatkan aplikasi website yaitu Google Meet.

Beberapa usulan kegiatan yang akan mendukung pencapaian tujuan peningkatan kualitas pembelajaran di sekolah SMP IT Daarul Istiqlal dan SMP IT Rahmat adalah:

a. Pelatihan pengembangan sistem pembelajaran berbasis online dengan aplikasi web GoogleMeet.
Aktivitas pelatihan bertujuan untuk melatih guru dalam mengembangkan kegiatan belajar dengan memanfaatkan IPTEK. Aktivitas ini dibagi dalam beberapa subaktivitas, yaitu (1) penyampaian materi pengembangan sistem pembelajaran dengan memanfatkan IPTEK, (2) pendampingan penyusunan bahan ajar mata perlajaran bahasa inggris, (3) presentasi dan diskusi diantara peserta pendampingan.

\section{b. Implementasi sistem pembelajaran berbasis online dengan aplikasiGoogle Meet.}

Implementasi sistem pembelajaran berbasis online dengan aplikasi Google Meet merupakan tahap lanjutan setelah pemaparan materi oleh ahli serta pendampingan penyusunan bahan ajar bahasa inggris tingkat SMP/MTS telah tersusun.

\section{c. Monitoring dan Evaluasi Implementasi kegiatan pembelajaran berbasis online.}

Aktivitas ini bertujuan untuk mengawasi, memeriksa, dan mengevaluasi implementasi evaluasi pembelajaran berbasis online terhadapsiswa.

\section{d. Adanya dokumen bahan ajar bahasa inggris yang telah disusun dalam workshop.}

\section{e. Pemanfaatan IPTEK dalam hal ini aplikasi Google Meet.}

Adanya dokumen rencana keberlanjutan program yang didukung oleh sekolah.

\section{WAKTU DAN PELAKSANAAN}

Waktu pelaksanaan kegiatan ini adalah Juli-Oktober 2020 bertempat di Sekolah SMP IT Daarul Istiqlal dan SMP IT Rahmat Marindal I Kecamatan Patumbak, Kabupaten Deli Serdang.

Tahapan pelaksanaan kegiatan pada program Pendampingan Sistem Pembelajaran Online Berbasis Aplikasi Google Meet Bagi Guru-Guru SMP IT Daarul Istiqlal dan SMP IT Rahmat secara sistematis mempertimbangkan alur dan mekanisme yang memudahkan untuk menjalankan program. Beberapa tahapan yang akan dilakukan adalah:

a. Melakukan audiensi, kordinasi dan sosialisasi program kepada stakeholder dalam hal ini pihak sekolah sebagai penerima manfaat program.

Kegiatan ini dilakukan untuk mempermudah tahapan awal dalammenjalankan program, selain itu dengan berkomunikasi kepada stakeholder lain maka dukungan terhadap program semakin kuat, dan sangat memungkinkan dapat dihubungkan kepada pihak lain dalam upaya keberlanjutan program. 
b. Penentuan lokasi pusat kegiatan pendampingan.

Saat ini sudah tersedia balai permanen yang dapat dimanfaatkan sebagai tempat pusat kegiatan pendampingan. Pada tempat ini juga nantinya akan difasilitasi dengan berbagai peralatan guna penunjang terlaksananya kegiatan.

c. Pelaksanaan Program Workshop Pendampingan Sistem Pembelajaran Online Berbasis Aplikasi Google Meet bagi Guru-Gur. Kegiatan ini akan memberikan keterampilan secara teknis kepada guru-guru dalam mempersiapkan pembelajaran berbasis online, menyusun bahan ajar mata pelajaran bahasa inggris dan format evaluasi pembelajaran berbasis online.

d. Penyelenggaraan Kegiatan Pembelajaran Online Berbasis Aplikasi Google Meet pada siswa di SMP IT Daarul Istiqlal dan SMP IT Rahmat.

Kegiatan ini dilakukan uji coba pembelajaran secara komprehensif kepada siswa dengan pemanfaatan IPTEK yang telah dipersiapkan oleh guru maupun sekolah sebagai pengerak kegiatan pembelajaran online.

e. Penyusunan rencana keberlanjutan kegiatan pembelajaran online sesuai dengan dasar kebutuhansekolah.

Kegiatan ini penting dilakukan sebagai bentuk exit strategi agar sekolah dapat mengembangkan program secara mandiri dan melanjutkan gerakan secara menyeluruh dan menjangkau pada penerima manfaat lebih luas.

\section{METODE PENDEKATAN PROGRAM}

Pendekatan yang ditawarkan untuk menyelesaikan permasalahan ini yaitu pendekatan partisipatif. Pendekatan partisipatif merupakan pendekatan yang mengikutsertakanpesertakegiatandalammenyusun rencana kegiatan, pelaksanaan kegiatan, dan evaluasi Program (Sudjana, 2005). Pada pendekatan ini, tim Pengabdian Pada Masyarakat bertindak sebagai fasilitator yang berperan untuk memfasilitasi dan mengarahkan proses pengembangan sistem pengembangan pembelajaran di SMP IT Daarul Istiqlal dan SMP IT Rahmat.

\section{PARTISIPASI MITRA}

Pelaksanaan program akan melibatkan mitra dan kelompok penerima manfaat.Hal ini akan mendorong tujuan besar program dapat dicapai secara bersamasama. Beberapa hal yang dilakukan mitra terkait dengan proses partisipasi adalah:

a. Partisipasi mitra diwujudkan denganpenyediaan fasilitas pendukung (sarana dan prasarana) kegiatan. Penyediaan tempat untuk pertemuan danpelatihan.

b.Keterlibatan stakeholder dengan sekolah.Keterlibatan stakeholder dan sekolah nantinya dapat berperan penting dalam pelaksanaan kegiatan pendampingan Sistem Pembelajaran Online Berbasis Aplikasi Google Meet bagi Guru-Guru SMP IT Daarul Istiqlal dan SMP IT Rahmat di era pandemi covid-19.

\section{HASIL DAN LUARAN YANG DICAPAI}

Kegiatan dan hasil pelaksanaan Program Pendampingan Sistem Pembelajaran Online Berbasis Aplikasi Google Meet Bagi Guru-Guru SMP IT Daarul Istiqlal dan SMP IT Rahmat Marindal I Kecamatan Patumbak, Kabupaten Deli Serdang ini ditunjukkan untuk mendpatkan luaran yang diharapkan. Kegiatan dan hasil dapat diungkapkan seperti berikut.

\section{a. Rekrutmen Peserta Program Kegiatan Pendampingan}

Kegiatan rekrutmen diawali dengan melaksanakan sosialisasi Kegiatan ke sekolah yang berupa pendampingan sistem pembelajaran online berbasis aplikasi Google Meet bagi guru-guru yang mendapatkan dana PNBP Program Pengabdian Masyarakat. Di samping itu, disosialisasikan juga kepada jurusan/prodi dan dosen-dosen di lingkungan Fakultas Bahasa dan Seni. Sosialisasi dilaksanakan pada bulan April. Pada program kegiatan ini dikuti oleh 17 guru SMP IT Daarul Istiqlal dan 15 SMP IT Rahmat Marindal I Kecamatan Patumbak, Kabupaten Deli Serdang. Sekolah mitra mendukung sepenuhnya penyelenggaraan program dan turut berkontribusi pada beberapa aktivitas atau kebutuhan program.

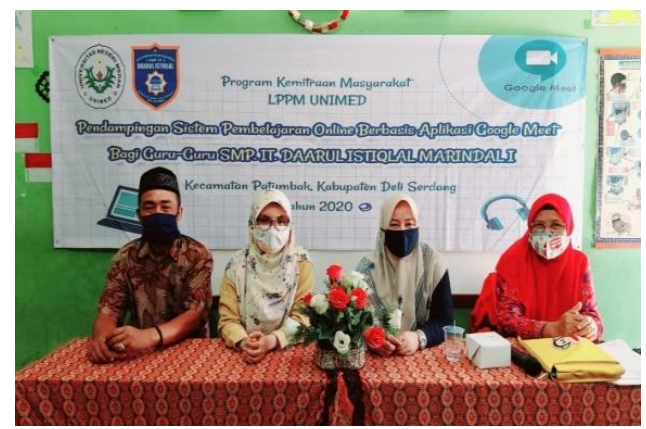

Gambar 5. Sosialisasi dan Audiensi Kegiatan Pendampingan Tim Pelaksana dengan Pihak Sekolah

b. PelaksanaanProgram Pendampingan melalui Workshop Pendampingan Sistem Pembelajaran Online Berbasis Aplikasi Google Meet bagi GuruGuru

Kegiatan ini akan memberikan keterampilan secara teknis kepada guru-guru dalam mempersiapkan 
pembelajaran berbasis online, menyusun bahan ajar mata pelajaran bahasa inggris dan format evaluasi pembelajaran berbasis online.
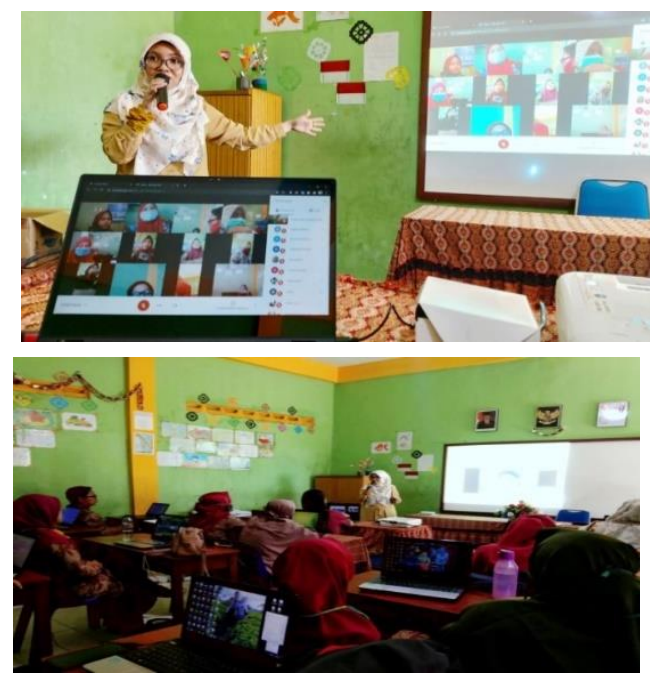

Gambar 6. Kegiatan workshop pendampingan guru dalam mempersiapkan pembelajaran berbasis online

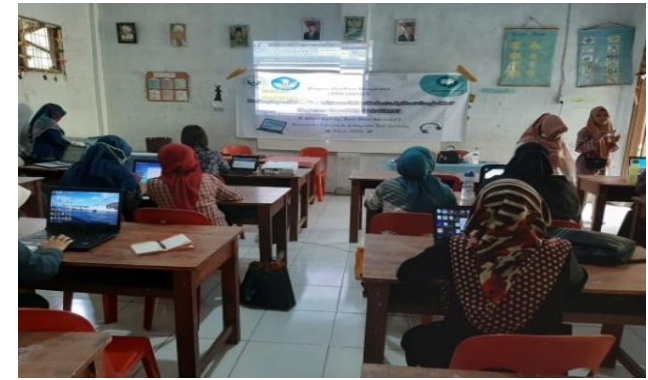

Gambar 7. Menyusun bahan ajar mata pelajaran bahasa inggris

\section{MONITORING DAN EVALUASI}

Kegiatan monitoring dan evaluasi merupakan kegiatan pengendalian internal agar pelaksanaan kegiatan Pendampingan yang berupa pengembangan Sistem Pembelajaran Online Berbasis Aplikasi Google Meet Bagi Guru-Guru SMP IT Daarul Istiqlal dan SMP IT Rahmat Marindal I Kecamatan Patumbak, Kabupaten Deli Serdang dapat berjalan lebih baik. Kegiatan ini dilakukan oleh tim pelaksana baik secara langsung maupun tidak langsung. Setiap kali dilakukan monitoring, selanjutnya dilakukan analisis evaluasi berdasarkan hasil monitoring. Evaluasi secara keseluruhan dilakukan melalui diskusi hasil monitoring dan evaluasi anggota tim. Hasil kegiatan monitoring dan evaluasi ini berupa saran/masukan kepada peserta maupun pembimbing dalam melaksanakan kegiatannya agar pencapaiannya sesuai yang direncanakan atau bahkan lebih baik lagi.

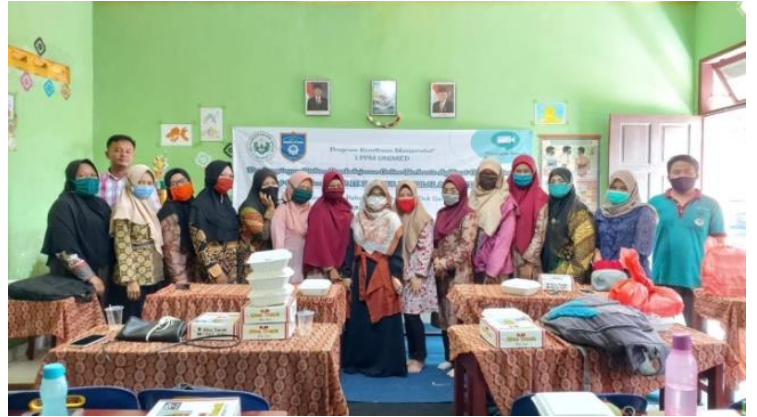

Gambar 8. Foto kegiatan evaluasi pembelajaran berbasis online

\section{LUARAN YANG DICAPAI}

Sebagaimana diungkapkan di muka, kegiatankegiatan yang telah dilaksanakan dan hasil diperoleh dari pelaksanaan Program Pendampingan Sistem Pembelajaran Online Berbasis Aplikasi Google Meet Bagi Guru-Guru SMP IT Daarul Istiqlal dan SMP IT Rahmat Marindal I Kecamatan Patumbak, Kabupaten Deli Serdang ini, dimaksudkan untuk mendapatkan luaran yang ditargetkan. Sesuai target luarannya, capaian luaran dari kegiatan ini dapat diungkapkan sebagai berikut.

\section{a. Publikasi ilmiah pada jurnal nasional/prosiding}

Publikasi ilmiah pada jurnal nasional atau prosiding seminar nasional pada tahun pertama ini baru dihasilkan dalam bentuk draf artikel. Draf tersebut belum sepenuhnya selesai karena belum direview oleh anggota tim maupun didiskusikan bersama. Capaian ini sesuai dengan target luaran tahun pertama, yaitu draf artikel.

\section{b. Publikasi pada media masa}

Publikasi pada media masa juga masih bersifat draf karena masih didiskusikan keluasan dan kedalaman kandungan substansinya. Capaian ini juga sesuai dengan target capaian luarannya.

\section{c. Materi Ajar Bahasa Inggris Berbasis Online (Buku Ajar)}

Buku ajar sebagai salah satu luaran dari pelaksanaan kegiatan ini baru berupa draf sebanyak 2 (dua) bab. Bab tersebut jug masih draf karena belum dikoreksi lebih lanjut. Bila luaran yang dicapai dibandingkan dengan target capaiannya, dapat disajikan dalam tabel berikut ini. 


\begin{tabular}{|c|c|c|}
\hline No. & \begin{tabular}{|l|} 
Jenis Luaran \\
\end{tabular} & Indikator Capaian \\
\hline \multicolumn{3}{|c|}{$\frac{1}{\text { Luaran Wajib }}$} \\
\hline 1 & $\begin{array}{l}\text { Satu artikel yang dipublikasikan melalui jurnal } \\
\text { berISSN online 1) }\end{array}$ & Ada \\
\hline 2 & $\begin{array}{l}\text { Publikasi pada media massa } \\
\text { cetak/online/repocitory Perguruan Tinggi 2) }\end{array}$ & Ada \\
\hline 3 & $\begin{array}{l}\text { Peningkatan daya saing (peningkatan kualitas, } \\
\text { kuantitas, serta nilai tambah barang, jasa, } \\
\text { diversivikasi produk, atau sumber daya lainnya } \\
\text { sesuai dengan jenis yang diusulkan) 3) }\end{array}$ & Ada \\
\hline 4 & $\begin{array}{l}\text { Peningkatan penerapan iptek di masyarakat } \\
\text { (mekanisasi, IT, dan manajemen) } 3 \text { ) }\end{array}$ & Ada \\
\hline 5 & $\begin{array}{l}\text { Perbaikan tata nilai masyarakat (seni budaya, } \\
\text { sosial, politik, keamanan, ketentraman, } \\
\text { pendidikan, kesehatan) 3) }\end{array}$ & Ada \\
\hline 6 & $\begin{array}{l}\text { Sertifikasi produk berupa sertifikasi halal, } \\
\text { BPPOM, SNI dan merk dagang 4) }\end{array}$ & \begin{tabular}{|l|} 
Tidak ada \\
\end{tabular} \\
\hline 7 & $\begin{array}{l}\text { Proposal Program Pengabdian kepada } \\
\text { Masyarakat multi tahun 4) }\end{array}$ & Penerapan \\
\hline \multicolumn{3}{|c|}{$\frac{1}{\text { Luaran Tambahan }}$} \\
\hline 1 & $\begin{array}{l}\text { Metode atau sistem; produk (barang atau jasa) } \\
\text { 3) }\end{array}$ & Ada \\
\hline $\begin{array}{l}\text { Kete } \\
\text { 1) I I } \\
\text { 2) Is } \\
\text { 3) Is } \\
\text { 4) Is }\end{array}$ & $\begin{array}{l}\text { tangan: } \\
\text { si dengan tidak ada, draf, submitted, reviewed, ac } \\
\text { idengan tidak ada, draf, proses editing, atau sud } \\
\text { idengan ada atau tidak ada } \\
\text { idengan tidak ada, draf, produk, atau penerapan }\end{array}$ & $\begin{array}{l}\text { cepted, atau published } \\
\text { h terbit }\end{array}$ \\
\hline
\end{tabular}

\section{RENCANA TAHAPAN SELANJUTNYA}

Tindak lanjut dari program pengabdian kepada masyarakat: Program Pendampingan Sistem Pembelajaran Online Berbasis Aplikasi Google Meet Bagi Guru-Guru SMP IT Daarul Istiqlal dan SMP IT Rahmat Marindal I Kecamatan Patumbak, Kabupaten Deli Serdang ini dengan cara memonitoring. Monitoring merupakan fungsi berkelanjutan yang menggunakan pengumpulan data secara sistematis berdasarkan indikator untuk memberikan informasi pada manajemen dan stakeholder yang berhubungan dengan kemajuan atau hasil yang diraih setelah menggunakan dana yang telah dialokasikan.

Selain itu akan dilakukan evaluasi secara periodik. Evaluasi merupakan penilaian yang sistematis dan objektif yang berkaitan dengan pelaksanaan atau hasil dari program, kebijakan berdasarkan perecanaan implementasi dan hasilnya. Tujuannya untuk mengetahui efektivitas dan efisiensi hasil, dampak maupun keberlanjutannya. Pendekatan yang akan digunakan dalam melakukan proses monitoring, evaluasi dan keberlanjutan program adalah dengan menggunakan Result - Based Management (RBM), dimana akan berfokus kepada beberapa hal penting, diantaranya:

a. Penentukan hasil realistik yang diharapkan;

b. Monitoring kemajuan melalui raihan hasil yang diharapkan; c. Menggunakan hasil dalam pembuatan keputusan manajemen;

d. Melaporkan kinerja manajemen.

\section{KESIMPULAN}

Berdasarkan hasil kegiatan didapat simpulan yaitu bahwa pembelajaran online dapat meningkatkan proses belajar siswa yang lebih mandiri, kreatif serta inovatif. Apabila materi yang disampaikan pada google meeting dirancang secara detail, dan sistematis, maka pembelajaran bahasa inggris di SMP IT Daarul Istiqlal Dan SMP IT Rahmat Marindal I Kecamatan Patumbak dapat meningkatkan kualitas pengetahuan siswa.

Kendala yang dihadapi dalam proses pembelajaran online ini dapat dilakukaan dengan kegiatan sosialisasi lebih intens diantara guru, guru dengan siswa. Selain itu, mencari solusi alternatif dalam menghadapi kendala diantaranya siswa mencari alternatif dengan memakai modem internet pribadi, warnet, atau dengan menggunakan aplikasi wifi.id berbayar yang telah disediakan oleh pihak sekolah guna meminimalisir kendala. Secara umum, pembelajaran berbasis online ini manarik, menantang kemandirian siswa dalam belajar dan sebagai solusi terbaik di massa pandemic Covid-19 yang menuntut physical distancing.

Pada tahap akhir kegiatan pengabdian ini didapatkan berdasarkan hasil pelaksanaan Pendampingan Sistem Pembelajaran Online Berbasis Aplikasi Google Meet Bagi Guru-Guru SMP IT Daarul Istiqlal dan SMP IT Rahmat Marindal I Kecamatan Patumbak,Kabupaten Deli Serdang didapat beberapa rekomendasi yang dijadikan pertimbangan lebih lanjut diantaranya.

a. Sekolah mengambil peranaktif mendukung program pengembangan selanjutnya akan melakukan kegiatan sebagai wujud eksistensi sebagai wadah produktif terhadap guru di sekolah.

b. Sekolah mencari alternative pembelajaran online dengan memanfaatkan aplikasi yang lebih beragam untuk mengatasi kendala jika sewaktuwaktuaplikasi google meet mengalami kendala dalam penggunaannya agar pemebelajaran jarak jauh tetap terlaksana dengan baik.

\section{UCAPAN TERIMA KASIH}

Ucapan terima kasih disampaikan kepada Rektor dan Lembaga Pengabdian Kepada Masyarakat, Universitas Negeri Medan atas dukungan pendanaan melalui program Pengabdian Kepada Masyarakat. Terima kasih juga disampaikan kepada kepala sekolah SMP IT Daarul Istiqlal and SMP IT Rahmat Patumbak, atas kerjasama yang telah terjalin dengan pengabdi.

\section{DAFTAR PUSTAKA}


Sudjana, Nana. 2005. Penilaian Hasil Proses Belajar Mengajar. Bandung. PT. Remaja Rosdakarya.

Hariningsih, S. (2005). Teknologi Informasi. Yogyakarta: Graha Ilmu.

Sadjati, 2012. Hakikat Bahan Ajar. Universitas Terbuka. repository.ut.ac.id/4157/1/IDIK4009M1.pdf bahan ajarpdf

https://pusdiklat.kemdikbud.go.id/surat-edaranmendikbud-no-4-tahun-2020-tentang-pelaksanaankebijakan-pendidikan-dalam-masa-daruratpenyebaran-corona-virus-disease-covid-1-9/.

https://www.medcom.id/pendidikan/inspirasipendidikan/JKRGWl5N-metamorfosis-duniapendidikan-di-masa-pandemi-covid-19

https://www.liputan6.com/regional/read/4214268/wasp ada-corona-covid-19-unimed-terapkan-wfh-hingga17-april-2020.

https://ulm.ac.id/id/2017/10/20/pemanfaatan-teknologiuntuk-pendidikan/ 